\title{
Repeat late instent-stenosis after an interval of four years in the same lesion after bare-metal and drug-eluting stent: a case report Frank Towae*, Ralf Zahn and Uwe Zeymer
}

\author{
Address: Department of Cardiology Herzzentrum Ludwigshafen, Medizinische Klinik B, 67063 Ludwigshafen, Germany \\ Email: Frank Towae* - frank@towae.com; Ralf Zahn -zahnr@klilu.de; Uwe Zeymer - zeymeru@klilu.de \\ * Corresponding author
}

Published: 3I December 2009

Cases Journal 2009, 2:9407 doi:10.1/86/1757-1626-2-9407

This article is available from: http://www.casesjournal.com/content/2///9407

(C) 2009 Towae et al; licensee BioMed Central Ltd.

This is an Open Access article distributed under the terms of the Creative Commons Attribution License (http://creativecommons.org/licenses/by/2.0), which permits unrestricted use, distribution, and reproduction in any medium, provided the original work is properly cited.
Received: 6 November 2009

Accepted: 31 December 2009

\begin{abstract}
In 200I, a 7I-year old male was admitted to our hospital with unstable angina. The angiography revealed 2-vessel disease with a $90 \%$ stenosis of the proximal LAD. A bare-metal stent was implanted. Four years later the angiography showed a $80 \%$ instent-stenosis in the bare-metal stent but no progress at the other coronary arteries. A DES was implanted. Again, four years later, the patient presented with non-ST-elevation myocardial infarction. Angiography showed a $90 \%$ instentrestenosis, again without any progession of coronary artery disease in the other vessels. Again a DES implanted. Therefore the processes involved in the late instent-stenosis were not influenced by the antiproliferative agent sirolimus
\end{abstract}

\section{Case presentation}

In April 2001 a 71-year old male (German) was admitted to our hospital with unstable angina. Blood pressure at admission was 160/80 $\mathrm{mmHg}$, LDL cholesterol was 127 $\mathrm{mg} / \mathrm{dl}$ and no diabetes exist. The electrocardiogram showed persistent atrial fibrillation with negative T-waves in leads $\mathrm{V}_{2}-\mathrm{V}_{5}$. The angiography revealed 2-vessel disease with a $90 \%$ stenosis of the proximal LAD (Figure 1a). A bare-metal stent (3.0/18 mm) was implanted (Figure $1 \mathrm{~b}$ ). Aspirin und clopidogrel were prescribed against stentthrombosis by the use of bare-metal stent for 4 weeks followed by oral anticoagulation with a vitamin-K antagonist (INR 2-3, phenprocoumon). Four years later the same patient was hospitalized once again with stable angina. Blood pressure was $130 / 70 \mathrm{mmHg}$ at admission and in the meanwhile the patient had diabetes. The angiography showed a $80 \%$ instent-stenosis in the bare-metal stent but no progress at the other coronary arteries (Figure 2a). This time a sirolimus-eluting stent (CYPHER $3.0 / 23 \mathrm{~mm}$ ) was implanted (Figure 2b). Aspirin, clopidogrel and the same oral anticoagulation (phenprocoumon) were given for three months against stent-thrombosis by use of drugeluting stent followed by oral anticoagulation alone. Again, four years later, in February 2009, the patient presented with non-ST-elevation myocardial infarction. Blood pressure was $120 / 80 \mathrm{mmHg}$ at admission and the patient presented with the same risk factors as prescribed. Angiography showed a 90\% instent-restenosis in the LAD again without any progession of coronary artery disease in the other vessels (Figure 3a). Again, a drug-eluting stent (XIENCE V 3.0/28 mm) implanted (Figure 3b).

\section{Discussion}

This case is unusual, because a late instent-stenosis was observed twice without any difference in the time interval of the clinical occurrence of the restenosis between baremetal and drug-eluting stent [1-3]. Usually restenosis occurs within 6 months after stent implantation. Thereafter the annual restenosis rate is only about $1-2 \%$. In this case, the implantation of a DES did not prolong the time- 


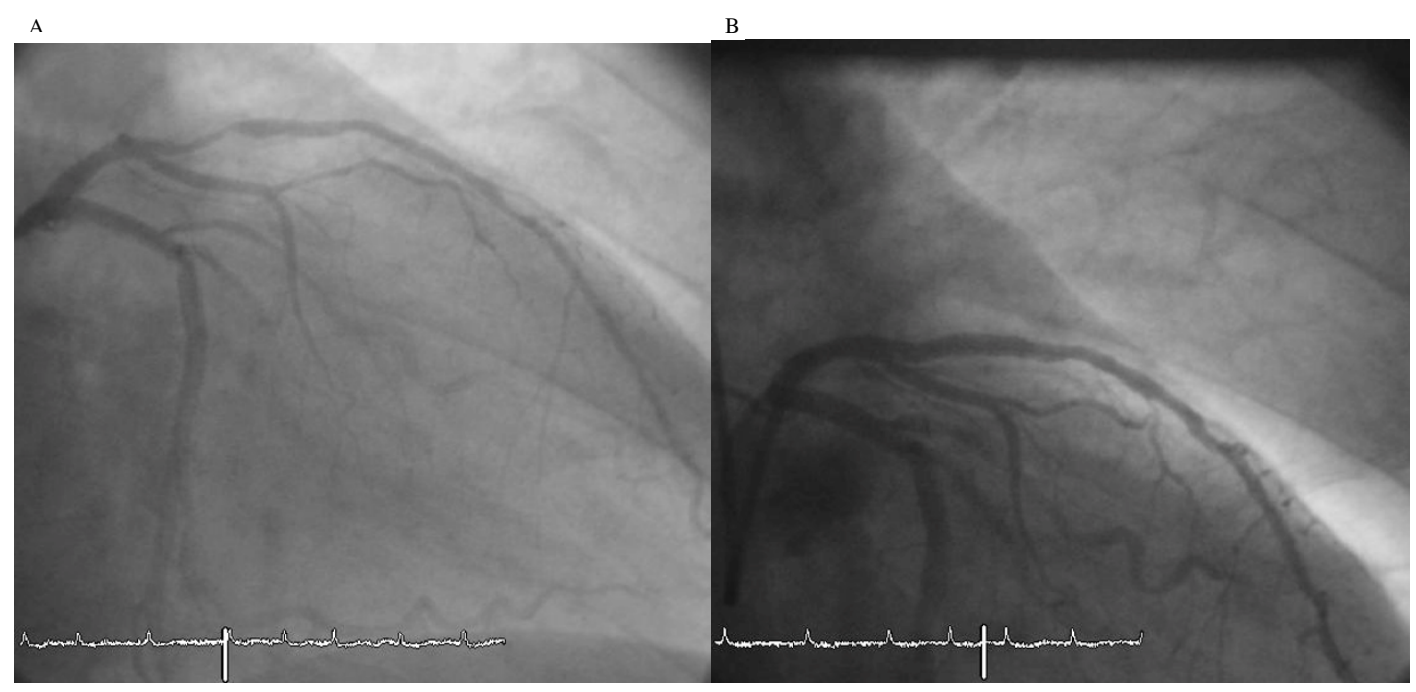

Figure I

Angiography after implantation of a bare-metal stent (200I).

interval until the restenosis became clinically apparent. Therefore, the processes involved in the late instent-stenosis in this patient were not influenced by the antiproliferative agent sirolimus $[4,5]$.

\section{Consent}

Written informed consent was obtained from the patient for publication of this case report and accompanying images. A copy of the written consent is available for review by the Editor-in-Chief of this journal.

\section{Competing interests}

The authors declare that they have no competing interests.
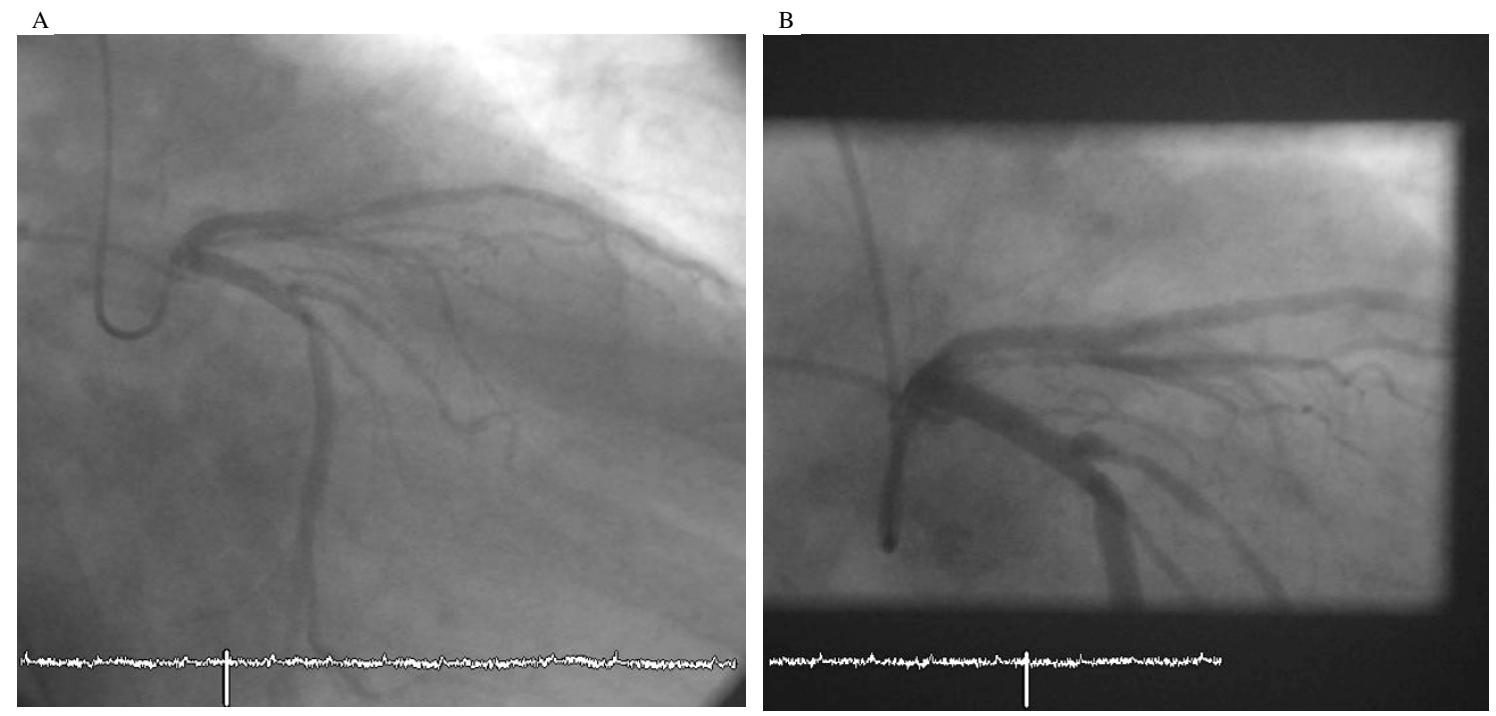

Figure 2

Second instent-stenosis in 2009. 
A

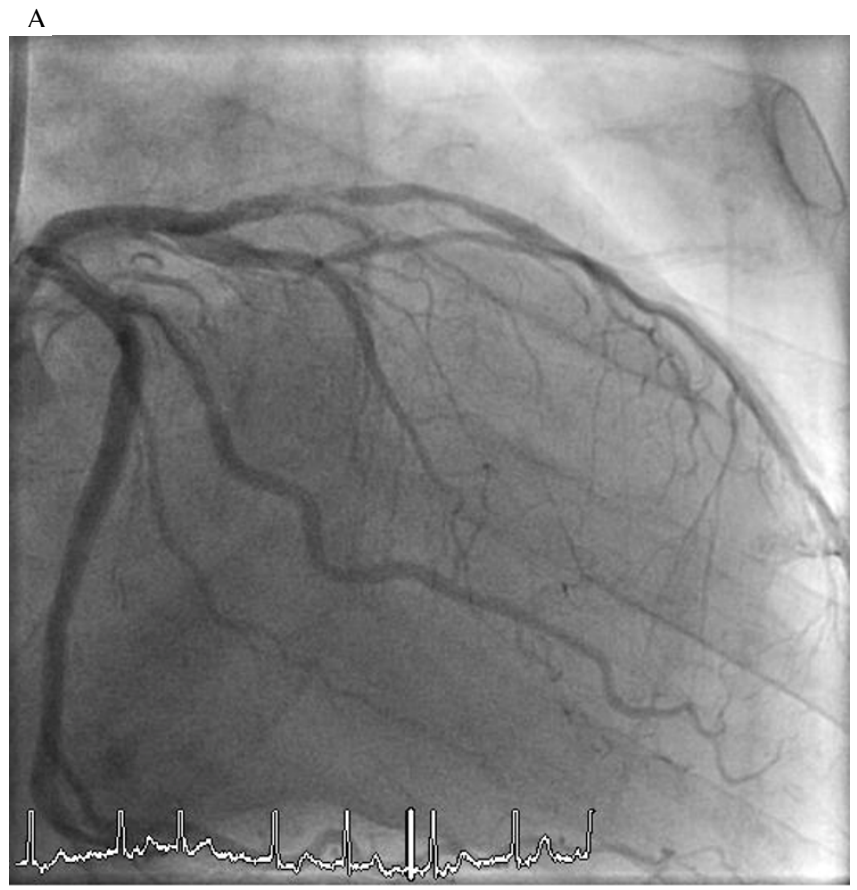

B

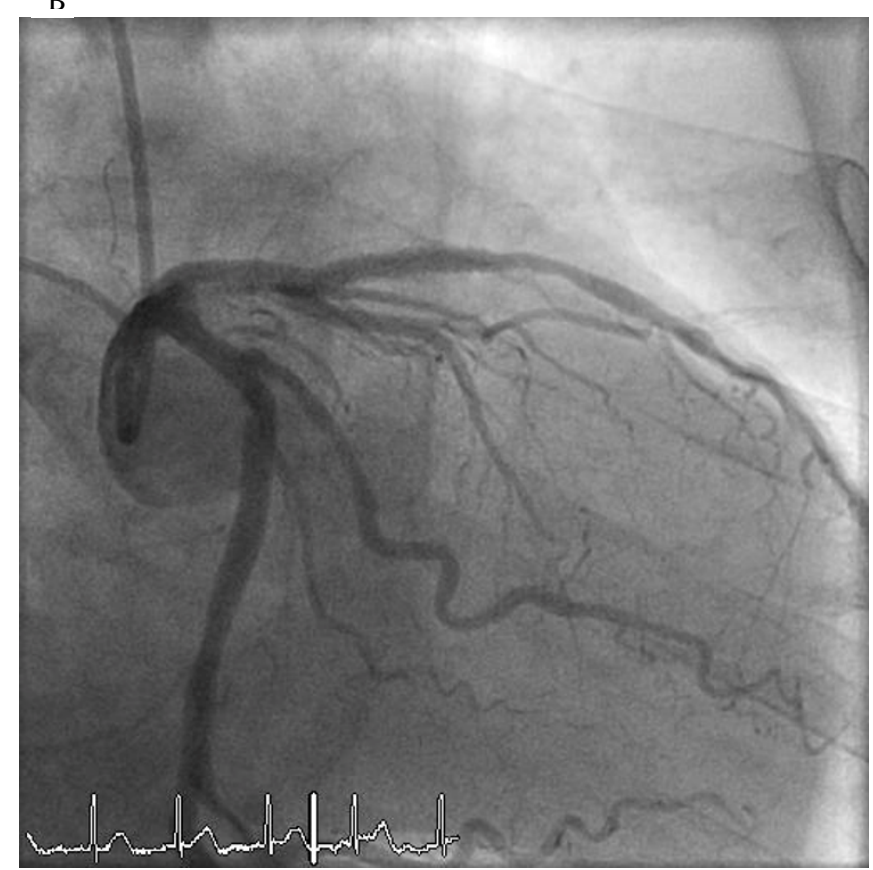

\section{Figure 3}

A. Second instent-stenosis in 2009. b. Final result after PCl with drug-eluting stent in 2009.

\section{Authors' contributions}

FT collected the data and wrote the case report. RZ reviewed the report and gave suggestions. UZ reviewed the report and gave suggestions.

All authors have read and approved the final manuscript.

\section{References}

I. Chieffo A, Park SJ, Meliga E, Sheiban I, Lee MS, Latib A, Kim YH, Valgimigli M, Sillano D, Magni V, Zoccai GB, Montorfano M, Airoldi F, Rogacka R, Carlino M, Michev I, Lee CW, Hong MK, Park SW, Moretti C, Bonizzoni E, Sangiorgi GM, Tobis J, Serruys PW, Colombo $A$ : Late and very late stent thrombosis following drug-eluting stent implantation in unprotected left main coronary artery: a multicentre registry. Eur Heart J 2008, 29( I 7):2 I08-2II I.

2. Spaulding C, Daemen J, Boersma E, Cutlip DE, Serruys PW: A pooled analysis of data comparing sirolimus-eluting stents with bare-metal stents. N Engl J Med 2007, 356:989-997.

3. Daemen J, Wenaweser P, Tsuchida K, Abrecht L, Vaina S, Morger C, Kukreja N, Juni P, Sianos G, Hellige G, van Domburg RT, Hess OM, Boersma E, Meier B, Windecker S, Serruys PW: Early and late coronary stent thrombosis of sirolimus-eluting and paclitaxeleluting stents in routine clinical practice: data from a large two-institutional cohort study. Lancet 2007, 369:667-678.

4. Kastrati A, Mehilli J, Pache J, Kaiser C, Valgimigli M, Kelbaek H, Menichelli M, Sabate M, Suttorp MJ, Baumgart D, Seyfarth M, Pfisterer ME, Schomig A: Analysis of 14 trials comparing sirolimus-eluting stents with bare-metal stents. N Engl J Med 2007, 356: 1030-1039.

5. Stone GW, Moses JW, Ellis SG, Schofer J, Dawkins KD, Morice MC, Colombo A, Schampaert E, Grube E, Kirtane AJ, Cutlip DE, Fahy M, Pocock SJ, Mehran R, Leon MB: Safety and efficacy of sirolimusand paclitaxel-eluting coronary stents. N Engl J Med 2007, 356:998-1008.
Publish with Biomed Central and every scientist can read your work free of charge

"BioMed Central will be the most significant development for disseminating the results of biomedical research in our lifetime. "

Sir Paul Nurse, Cancer Research UK

Your research papers will be:

- available free of charge to the entire biomedical community

- peer reviewed and published immediately upon acceptance

- cited in PubMed and archived on PubMed Central

- yours - you keep the copyright
BioMedcentral 